$2019,20(1)$, pp. $34-53$, DOI: 10.18038/aubtda. 474807

\title{
EVALUATION OF THE EFFICIENCY OF PUBLIC HIGH SCHOOLS IN IZMIR/TURKEY USING DEAHP APPROACH
}

\author{
Reyhan AYNA ${ }^{1}$,Özge ELMASTAŞ GÜLTEKIN ${ }^{1, *}$ \\ ${ }^{1}$ Department of Statistics, Faculty of Science, Ege University, İzmir, Turkey
}

\begin{abstract}
This study is carried out to assess the relative efficiency of the Anatolian high schools in İzmir /Turkey and to guide inefficient educational institutions to become efficient. Firstly, efficiency measurement is performed by Data Envelopment Analysis (DEA) model. Instead of assigning equal weights to the input and output variables, the analysis is repeated by assigning weights with the aid of the Analytic Hierarchy Process(AHP) model. 3 input and 3 output variables are determined in the study and 47 Anatolian High Schools are analyzed. In İzmir, this study is important since it is the first study to assess the efficiency of Anatolian high schools with Data Envelopment Analytic Hierarchy Process (DEAHP) integrated model.
\end{abstract}

Keywords: Education, DEA, AHP, Efficiency

\section{INTRODUCTION AND LITERATURE REVIEW}

Education is one of the most important elements for improvement and development of a nation. For this reason, it is extremely important to carry out studies related to educational institutions and contribute to increase the quality of institutions.

Given that education institutions have crucial functions for individuals and therefore for the whole nation, it would be utterly crucial to conduct efficiency analyses of institutions and to set targets for ensuring efficient education in those which are not operating efficiently.

DEA is a linear programming model to assess the relative efficiency of units when there are multiple inputs and outputs. The model is often considered to be an ideal solution for its availability in analyses with multiple inputs and outputs and its comparatively flexible structure. In an organization with multiple inputs and outputs where each variable is significant in varying degrees, outputs are categorized and included in the analysis according to their degree of significance by using AHP to attain healthier results.

Anatolian High Schools are a special type of public high schools in Turkey. The duration of education is normally 4 years but in some schools, students are required to do an extra year of prep class. They are particularly designed to educate students to pursue a university degree according to their interests and academic success. This study presents the analyses on the efficiency of Anatolian high schools in İzmir, Turkey and evaluates the study data with DEAHP integrated model. This study bears much importance since it is the first study to evaluate the efficiency of Anatolian high schools in the region.

There are a large number of studies conducted by using either DEA or AHP models. To name a few examples conducted with the integrated model; [1] researchers suggested a two step model for organizations with multiple inputs and outputs in studies conducted with (DEAHP) integrated model: in the first step the data are analyzed with DEA and in the second with AHP; [2] the researchers measured relative efficiency of energy efficiency technologies in the national energy efficiency plan sector by using AHP and DEA integrated models. In practice, CCR model used to be conducted to

*Corresponding Author: ozge.elmastas@ege.edu.tr

Received: 25.10.2018 Accepted: 09.03.2019 
assess outputs while this new approach indicated that AHP and DEA integrated model can be an ideal model for the solution of multi-criteria decision making problems in the energy sector; [3] the researchers conducted a study on the choice of warehouse operator network by combining DEA and AHP models; [4] a study was conducted on the suppliers for BEKO company, which analyzed the data by using AHP model and then the same data by using DEAHP integrated model; [5] the researchers evaluated the risks of different bridge designs by using DEA/AHP integrated model to evaluate criteria (with AHP model) and to determine the values (with DEA model); [6] in a study on the efficiency of notebooks in a wide range of brands and models, the variable returns to scale (BCC) model was used by using EMS package program to analyze 2 different efficiency analyses; this first analysis was conducted with DEA model and the second analysis was conducted after adding weights to DEA model with the help of AHP model; [7] the researchers enlisted the activities of local governments in China using the DEA and AHP integrated model; [8] a study was also conducted to evaluate the efficiency of 26 public hospitals in Ankara with 4 input variables and 5 output variables. The efficiency analysis was performed with DEA model initially, then weights were assigned to input and output variables with the help of AHP model and the efficiency analysis was repeated with DEA model. In the DEA analysis, 13 hospitals were found to be effective whereas 10 hospitals were noted to be efficient in the analysis performed with AHP-weighted DEA model; [9] in a similar study, the researchers conducted a DEAHP analysis with the data obtained from a steel plant in India. The activities of 8 financial years were evaluated by using the CCR model; [10] in another study conducted to evaluate the efficiency of 12 faculties in Serbia, constant returns to scale model was used, which identified 2 input variables and 3 input variables; [11] the export efficiency of 30 textile and pret a porter companies was assessed with DEA model, which included data from 2012 by using 4 input and 1 output variables. AHP model was used to determine the factors of efficiency for those with $100 \%$ efficiency; [12] 8 non-life insurance companies in Turkey conducted performance evaluation tests for financial rates by using ratio analysis based on DEA and AHP models; [13] in another study, the researchers performed an analysis by integrating grey relational analysis (GRA) into DEA and AHP models in a multi-hierarchical structure; and [14] in a relevant study, the researchers proposed a integrated model of DEA and AHP to evaluate efficiency in higher education in Greece.

\section{BASIC CONCEPTS: PERFORMANCE AND EFFICIENCY}

Performance refers to a qualitative and quantitative statement that characterizes to what extent an individual, a group, or an organization can attain their targets [15]. Seven dimensions of performance in an organizational business structure are efficiency, outputs and inputs, performance, quality, innovation, quality of work life, profitability and budget compatibility [16]. Considering the unlimited demand and limited supply of goods and services, it can be reasonably presumed that efficiency and performance would remain at the heart of organizational structures [17]. Productivity is an indicator obtained by the ratio of the production amount to the total input, namely, acquiring the highest output with a certain amount of input or a certain amount of output with the lowest input [18]. The efficiency is a performance dimension that demonstrates how an enterprise makes use of its resources [19]. In other words, it shows the extent to which actual performance should be approximate to the desired performance [20]. The efficiency concept is directly related to inputs, which indicates the optimum use of inputs. As the rate of efficiency gets closer to 1, the inputs are regarded as being used at an optimum level. Thus, efficiency is expressed by the ratio of the actual output to the maximum output obtained [21]. Efficiency types are categorized as technical efficiency, scale efficiency and allocation efficiency.

\section{Efficiency= Actual output /Actual capacity}




\section{DEA AND AHP MODELS}

\subsection{DEA}

DEA was first designed by Charnes, Cooper and Rhodes in 1978 [22]. Indeed, it has become one of the most popular models in operations research and management science. The success of analysis lies in its task-oriented approach focusing on the relative efficiency of decision making units (DMU) [23]. DEA is a nonparametric model that measures the relative efficiency of DMUs with multiple inputs and outputs [24]. DEA generates efficiency ratios by proportioning total weighted outputs to total weighted inputs for DMUs.

$$
\operatorname{Max} \frac{\sum_{r=1}^{s} u_{r} y_{r j}}{\sum_{i=1}^{m} v_{i} x_{i j}}, \quad j=1, \ldots, n \quad \frac{\sum_{r=1}^{s} u_{r} y_{r k}}{u_{r}, v_{i} \geq 0, \quad} \leq 1, \quad k=1, \ldots, n
$$

In this formula, $n$ shows the number of DMUs, $x_{i j}$ shows $i$. input of $j$.DMU, $y_{r j}$ shows $r$. output of $j$.DMU, $u_{r}$ shows the weight of the $r$.output, $v_{i}$ shows the weight of the $i$.input, $m$ shows the number of inputs and $s$ shows the number of outputs [25].

The implementation of DEA analysis consists of the following stages: Selection of DMUs, selection of inputs and outputs, data collection and reliability, establishing DEA model and efficiency measurement, efficiency values and efficiency limits, establishing reference groups, target setting for inefficient DMUs and assessment.

DEA models are classified in two groups as input-oriented and output-oriented. The objective in the input-oriented model is to investigate how much input can be reduced to achieve a certain level of output. The main point in the input-oriented model is to determine the optimum input composition to obtain maximum output. The output-oriented model, on the other hand, explores how much output can be achieved with a particular input composition. Having created the model, efficiency is measured with the help of the programs used to devise linear programming models [26].

DEA models are classified differently with reference to a variety of criteria. At first, the CCR model was developed for input-oriented and output-oriented studies based on the constant returns to scale but later on the BCC model was developed for variable returns to scale. However, other models have already been developed to deal with different classifications [27].

\subsubsection{CCR (Charnes, Cooper, Rhodes) model}

This model was developed by Charnes, Cooper and Rhodes in 1978 and it has remained as the most basic DEA model [22]. The model was derived from Farrell's study on the measurement of efficiency in 1957 [28]. The model assumes that all DMUs operate on an ideal scale [29]. The CCR model is categorized as the input-oriented CCR model and the output oriented CCR model.

The input-oriented CCR model aims to minimize inputs while attaining a specific output level. The outputoriented CCR model seeks to maximize output without requiring more than observed input values [30]. 


\begin{tabular}{|l|l|}
\hline \multicolumn{1}{|c|}{ The input-oriented CCR model } & The output-oriented CCR model \\
\hline$E_{k}=\operatorname{Max} \frac{\sum_{r=1}^{p} u_{r} Y_{r k}}{\sum_{i=1}^{m} v_{i} X_{i k}}$ & $\sum_{k}=\operatorname{Min} \frac{\sum_{i=1}^{m} v_{i} X_{i k}}{\sum_{r=1}^{p} u_{r} Y_{r k}}$ \\
$\sum_{r=1}^{p} u_{r} Y_{r j}$ \\
$\sum_{i=1}^{m} v_{i} X_{i j}$ & $\sum_{i=1}^{m} v_{i} X_{i j}$ \\
$u_{r} \geq \varepsilon$ & $\frac{\sum_{r=1}^{p} u_{r} Y_{r j}}{v_{r} \geq \varepsilon}$ \\
$v_{i} \geq \varepsilon$ & $u_{r} \geq \varepsilon$ \\
$j=1, \ldots, n$ & $v_{i} \geq \varepsilon$ \\
$r=1, \ldots, p$ & $j=1, \ldots, n$ \\
$i=1, \ldots, m$ & $r=1, \ldots, p$ \\
\hline
\end{tabular}

In this formula, $n$ indicates the number of DMUs, $p$ number of output, $m$ the number of input, $u_{r}$ the weight assigned to $r$.output by $k$.DMU, $v_{i}$ the weight assigned to $i$. input by $k$.DMU, $Y_{r k} r$. output generated by $k$.DMU, $X_{i k} i$. input generated by $k$.DMU, $Y_{r j} r$. output generated by $j$.DMU and $X_{i j} i$. input generated by $j$. DMU and $\varepsilon$ a sufficiently small positive number [31].

\subsubsection{BCC (Banker, Charnes, Cooper) model}

This model was developed by Banker, Charnes and Cooper in 1984 with the assumption of variable returns to scale (VRS) and is referred as the BCC model in literature [32]. According to Bowlin in 1987 , the density vector $\lambda$ in the variable returns to scale model is confined with the sum of the decision variables equal to 1 [33], which is the main difference between the BCC model and the CCR model. Consequently, BCC models are used to measure only technical efficiency with the assumption of variable returns to scale. While a DMU must be efficient in both technical aspects and scalewise in a CCR model, it is quite eligible in BCC model if it is only technically efficient. The measurement focus in a CCR model is total efficiency whereas in BCC model it is only technical efficiency [34].

The input oriented BCC model seeks to determine the minimum input level to achieve a certain amount of output [18]. The output-oriented BCC model, on the other hand, delineates a certain amount of input and maximum output level [35].

\begin{tabular}{|l|l|}
\hline The input-oriented BCC model & The output-oriented BCC model \\
\hline$E_{k}=\operatorname{Max} \frac{\sum_{r=1}^{p} u_{r} Y_{r k}-\mu_{0}}{\sum_{i=1}^{m} v_{i} X_{i k}}$ & $E_{k}=\operatorname{Min} \frac{\sum_{i=1}^{m} v_{i} X_{i k}-\mu_{0}}{\sum_{r=1}^{p} u_{r} Y_{r k}}$ \\
$\left(\sum_{r=1}^{p} u_{r} Y_{r j}-\mu_{0}\right)$ & $\left(\sum_{i=1}^{m} v_{i} X_{i j}-\mu_{0}\right)$ \\
$\frac{\left(\sum_{i=1}^{m} v_{i} X_{i j}\right)}{\left.\sum_{r=1}^{p} u_{r} Y_{r j}\right)} \geq 1$ \\
$u_{r} \geq \varepsilon$ & $u_{r} \geq \varepsilon$ \\
$v_{i} \geq \varepsilon$ & $v_{i} \geq \varepsilon$ \\
$j=1, \ldots, n$ & $j=1, \ldots, n$ \\
$r=1, \ldots, p$ & $r=1, \ldots, p$ \\
$i=1, \ldots, m$ & $i=1, \ldots, m$ \\
$\mu_{0}:$ unrestricted & $\mu_{0}:$ unrestricted \\
\hline
\end{tabular}


In this formula, $u_{r}$ indicates the weight assigned to the $r$.output by $k$.DMU, $v_{i}$ the weight assigned to $i$. input by $k$.DMU, $Y_{r k} r$. output generated by $k$.DMU, $X_{i k} i$. input used by $k$.DMU, $Y_{r j} r$. output generated by $j$.DMU, $X_{i j} i$. input generated by $j . D M U$ and $\varepsilon$ a sufficiently small positive number [26].

\subsection{AHP}

The AHP model involves hierarchization of decision making problems with multiple criteria, the evaluation of the relative significance of the decision criteria, comparison of the decision alternatives according to each criterion, and establishing priority values and a ranking for each decision alternative. At the top of the decision hierarchy, the main objective is formed with a lower level decision criteria and decision alternatives at the bottom level [5].

The implementation of AHP consists of following 4 stages, which are identifying the problem, binary comparison of the criteria, calculation of the weights and consistency analysis.

To obtain the binary comparison matrices of the criteria, the relative significance scale is formed with numbers indicating the significance of the criteria, which ascertains individual judgments regarding all the criteria [36]. 1-9 scale was developed by Saaty in 1980 to indicate their significance levels [37].

Table 1. AHP scale levels [36]

\begin{tabular}{|c|l|l|}
\hline $\begin{array}{l}\text { Significance } \\
\text { Level }\end{array}$ & Definition & Explanation \\
\hline 1 & Equally Significant & Two criteria are equally significant. \\
\hline 3 & Moderately Significant & Experience and judgment prioritize one criterion over the other. \\
\hline 5 & Strongly Significant & Experience and judgment deliberately prioritize one criterion over the other. \\
\hline 7 & Very Strongly Significant & One criterion is clearly prioritized over the other. \\
\hline 9 & Absolutely Significant & Evidence showing the priority of one criterion over the other is highly reliable. \\
\hline $2,4,6,8$ & Intermediate Values & $\begin{array}{l}\text { These are values intermediating between two sequential judgments when } \\
\text { agreement is needed. }\end{array}$ \\
\hline
\end{tabular}

If the binary comparison that reflects the personal judgment of the decision-maker based on the scale 1-9 are shown with $A$, then $a_{i j}$ indicates the importance of feature $i$ according to the feature $j$.

The binary comparison matrix is obtained as follows when $\mathrm{m}$ indicates the number of criteria to be evaluated:

When $A=\left(a_{i j}\right)_{m x m}=\left[\begin{array}{ccc}a_{11} & \cdots & a_{1 m} \\ \vdots & \ddots & \vdots \\ a_{m 1} & \cdots & a_{m m}\end{array}\right], i, j=1, \ldots, m, \quad a_{i j}>0$,

if $a_{i j}=1 / a_{j i}$ and $a_{i i}=1, a_{i j}=a_{i k} a_{k j}, i, j, k=1, \ldots, m$ equalities are provided, the matrix $A$ is fully consistent, otherwise, it is inconsistent [5].

Having defined $A$ matrix, its elements need be normalized by dividing the value of each element to the sum of the column. In a normalized matrix, significance values (weight values) are found by calculating the arithmetic mean of each row.

Given that $b_{j}$, j.indicates the total value of a column, the total value of a column is calculated with the formula below.

$$
b_{1}=\sum_{i=1}^{m} a_{1 i}
$$

Then, the elements of $A$ matrix is divided to the total value of their column with that formula: 


$$
c_{i j}=\frac{a_{i j}}{b_{i}}
$$

As a result, matrix $C$ with $m \times m$ dimension is found by normalizing binary comparison matrix.

$$
C=\left[\begin{array}{ccc}
c_{11} & \cdots & c_{1 m} \\
\vdots & \ddots & \vdots \\
c_{m 1} & \cdots & c_{m m}
\end{array}\right]
$$

$C$ matrix helps to specify relative percentage significance values (i.e. their weight values) of the criteria.

$$
w_{i}=\frac{\sum_{j=1}^{m} c_{i j}}{m}
$$

$W$ column vector refers to the percentage weight of the criteria calculated with the arithmetic mean of the rows in a $C$ matrix [36].

$$
W=\left[\begin{array}{c}
w_{1} \\
w_{2} \\
\cdot \\
w_{m}
\end{array}\right]
$$

The validity, and therefore factuality, of the results relies on the consistency of binary comparison matrices. The consistency of results is confirmed with consistancy rates (CR). Consistency analysis also asisists to highlight incorrect judgments and to reduce errors [36]. To measure the consistency of binary matrices, $\mathrm{CR}$ is calculated by dividing consistency index (CI) to random index (RI). To measure the former, $\lambda_{\max }$ defines the biggest eigenvalue of $\mathrm{A}$ matrix and is calculated with $\left(\mathrm{A}-\lambda_{\max } \mathrm{I}\right) w=0$ formula. The latter, on the other hand, is identified with the size of binary matrix. RI values from 1 to 10 is shown in Table 2.

$$
C I=\frac{\lambda_{\max }-m}{m-1} \quad, \quad C R=\frac{C I}{R I}
$$

Table 2. RI values[2]

\begin{tabular}{|c|c|c|c|c|c|c|c|c|c|c|}
\hline $\boldsymbol{m}$ & $\mathbf{1}$ & $\mathbf{2}$ & $\mathbf{3}$ & $\mathbf{4}$ & $\mathbf{5}$ & $\mathbf{6}$ & $\mathbf{7}$ & $\mathbf{8}$ & $\mathbf{9}$ & $\mathbf{1 0}$ \\
\hline $\mathbf{R I}$ & 0 & 0 & 0,58 & 0,90 & 1,12 & 1,24 & 1,32 & 1,41 & 1,45 & 1,49 \\
\hline
\end{tabular}

If $\mathrm{CR}$ value is less than 0,10 , the comparisons of decision makers are considered to be consistent at satisfactory levels; if not, it is noted to be inconsistent, which indicates that AHP can't produce significant results [2].

\subsection{DEA and AHP Integrated Models}

The DEA model assesses the efficiency of DMUs by using quantitative inputs and outputs. However, the inputs and outputs in an analysis may not be equally significant. If this is the case, instead of assigning equal weights to the variables, the priority of these variables must be identified in advance [8]. The DEAHP integrated model, which was first developed by Ramanathan in 2006 [38], allows an analysis of the weights of inputs and outputs [4].

The limitations of DEA are that the efficiency levels should not exceed $100 \%$ and the weights must be positive. A third limitation of DEA can be to include an expert opinion in regard to weights, which can be created by using the AHP model. The mathematical representation of the third limitation that includes the expert opinion via binary comparison matrices of AHP is as follows: 


$$
A=\left[\begin{array}{ccc}
a_{11} & \cdots & a_{1 m} \\
\vdots & \ddots & \vdots \\
a_{m 1} & \cdots & a_{m m}
\end{array}\right]
$$

If binary comparison matrix for output-oriented AHP is $A$, the weight limitations are as follows:

$$
\frac{u_{1}}{u_{2}} \geq a_{12} \rightarrow u_{1} \geq a_{12} u_{2} \rightarrow u_{1}-a_{12} u_{2} \geq 0
$$

$$
\begin{gathered}
\frac{u_{m-1}}{u_{m}} \geq a_{(m-1) m} \rightarrow u_{m-1} \geq a_{(m-1) m} u_{m} \rightarrow u_{m-1}-a_{(m-1) m} u_{m} \geq 0 \\
B=\left[\begin{array}{ccc}
b_{11} & \cdots & b_{1 p} \\
\vdots & \ddots & \vdots \\
b_{p 1} & \cdots & b_{p p}
\end{array}\right]
\end{gathered}
$$

If binary comparison matrix for input-oriented AHP is $B$, the weight limitations are as follows:

$$
\begin{aligned}
& \frac{v_{1}}{v_{2}} \geq b_{12} \rightarrow v_{1} \geq b_{12} v_{2} \rightarrow v_{1}-b_{12} v_{2} \geq 0 \\
& \text {. } \\
& \text {. } \\
& \frac{v_{p-1}}{v_{p}} \geq b_{(p-1) p} \rightarrow v_{p-1} \geq b_{(p-1) p} v_{p} \rightarrow v_{p-1}-b_{(p-1) p} v_{p} \geq 0
\end{aligned}
$$

By representing these inequalities in line with linear programming, the problem can be solved by simplex or similar algorithms [6].

\section{EVALUATION OF THE EFFICIENCY OF ANATOLIAN HIGH SCHOOLS IN IZMIR WITH DEAHP MODEL}

This analysis was conducted to evaluate the efficiency of Anatolian high schools in İzmir by using DEAHP integrated model.

\subsection{Purpose and Scope of the Research}

A literature review suggested that DEAHP integrated model has been extensively used in a variety of studies on health, education and so on. The review particularly focused on educational studies and no previous study has been reported on the Anatolian high education institutions in İzmir, Turkey. The primary purpose of this study is to determine the efficiency of certain Anatolian high schools in İzmir and to make suggestions to improve the efficiency of inefficient schools. DEAHP integrated model was used as the study model with a view to ascertain that the expert opinions are included in the analysis while determining the efficiency of the schools to achieve healthier results. Two different models were carried out to analyze the data. Initially, the efficiency evaluation was conducted with DEA. Afterwards, by adding weight values of the input and output variables, the analysis was repeated. 
The study mainly consists of the following steps:

1- Selection of DMUs

2- Establishing input and output variables in DMUs,

3- To carry out the analysis with DEA model to identify the effective and ineffective DMUs, 4- Assigning weights to the input and output variables of DMUs in accordance with the expert opinions obtained with the help of AHP model,

5- Implementation of efficiency analysis by using DEAHP integrated model and retesting efficiency and inefficiency of DMUs.

6- Comparison and discussion of the results obtained with DEA and DEAHP models

\subsection{Selection of DMUs}

To assure homogeneity, 47 Anatolian High Schools were selected as DMUs in central districts of İzmir province (Balçova, Buca, Gaziemir, Çiğli, Bornova, Konak, Karşıyaka) on the condition that they had the same inputs and outputs. Imam-Hatip High Schools and Vocational and Technical High Schools were excluded in the study for differences in their education programs. These 47 high schools selected for the study are given in Table 3 .

Table 3. DMUs for the study

\begin{tabular}{|c|c|c|c|}
\hline Number & School & Number & School \\
\hline 1 & Balçova anatolian high school & \begin{tabular}{|l|}
25 \\
\end{tabular} & Necip Fazıl Kısakürek anatolian high school \\
\hline 2 & Nevvar Salih İşgören anatolian high school & 26 & Gaziemir Nevvar Salih İşgören anatolian high school \\
\hline 3 & Salih Dede anatolian high school & 27 & Gaziemir anatolian high school \\
\hline 4 & Bornova anatolian high school & 28 & Kipa 10.Y1l anatolian high school \\
\hline 5 & Bornova Cem Bakioğlu anatolian high school & 29 & Karşıyaka Atakent anatolian high school \\
\hline 6 & Bornova Hatice Güzelcan anatolian high school & 30 & Karşıyaka Behçet Uz anatolian high school \\
\hline 7 & Bornova Suphi Koyuncuoğlu anatolian high school & 31 & Karşıyaka Cihat Kora anatolian high school \\
\hline 8 & Çimentaş anatolian high school & 32 & Şemikler anatolian high school \\
\hline 9 & Gülsefa Kapancıoğlu anatolian high school & 33 & Vali Erol Çakır anatolian high school \\
\hline 10 & Hayrettin Duran anatolian high school & 34 & Karşıyaka anatolian high school \\
\hline 11 & Yunus Emre anatolian high school & 35 & Emlakbank Süleyman Demirel anatolian high school \\
\hline 12 & S1dıka Rodop anatolian high school & 36 & Gazi anatolian high school \\
\hline 13 & Betontaş anatolian high school & 37 & Karşıyaka high school \\
\hline 14 & Buca 85.Y11 anatolian high school & 38 & 50.Y1l anatolian high school \\
\hline 15 & Fatih Sultan Mehmet anatolian high school & 39 & İzmir Kız high school \\
\hline 16 & İzmir Buca Aybers Hikmet Karabacak anatolian high school & 40 & Karataş anatolian high school \\
\hline 17 & Buca Fatma Saygın anatolian high school & 41 & Konak anatolian high school \\
\hline 18 & Şirinyer anatolian high school & 42 & Konak Hürriyet anatolian high school \\
\hline 19 & Gürçeşme anatolian high school & 43 & Namık Kemal high school \\
\hline 20 & Buca anatolian high school & 44 & Selma Yiğitalp anatolian high school \\
\hline 21 & Büyükçiğli anatolian high school & 45 & Vali Vecdi Gönül anatolian high school \\
\hline 22 & Çiğli Teğmen Ali Rıza Akıncı anatolian high school & 46 & Konak Kenan Evren anatolian high school \\
\hline 23 & Tuğba Özbek anatolian high school & 47 & Atatürk High School \\
\hline 24 & Çiğli Yıldız Tınas İzmirlioğlu anatolian high school & & \\
\hline
\end{tabular}

\subsection{Establishing input and output variables in DMUs}

Establishing input and output variables is of utmost important and the variables that best express the process should be selected in order to measure the efficiency with DEA model. A large number of input and output variables decreases the discriminatory power of DEA [39]. The input and output variables used in the field of education are taken as a reference and also they are determined by considering expert opinions. Therefore, the review included studies on education with DEA and the most significant input and output variables in measuring the efficiency of Anatolian high schools that fully represent the process are available in Table 4. 
Table 4. Input and output variables

\begin{tabular}{|l|l|}
\hline Input variables & Output variables \\
\hline Number of teachers & Number of graduate students \\
\hline Number of students & Number of students pursuing a university degree \\
\hline Number of classrooms & YGS+LYS Success Rate \\
\hline
\end{tabular}

Number of teachers: The total number of teachers working in the selected schools in the 2015-2016 academic year.

Number of students: The number of students attending the selected schools in the 2015-2016 academic year. Besides, it also indicates the school preference of parents as well as the school's capacity to teach students, which, therefore, is also considered as an input criterion.

Number of classrooms: The total physical area. It is the total number of classrooms available in the selected schools in the 2015-2016 academic year.

Number of graduate students: The total number of students who graduated from the selected schools at the end of the 2015-2016 academic year.

Number of students pursuing a university degree: The number of students enrolled in undergraduate, associate and open education courses at selected schools at the end of the 2015-2016 academic year.

YGS + LYS success rate: The ratio of the number of students enrolled in a higher education institution (undergraduate + associate + open education) to the number of students entering the university exam in the same year.

The researchers obtained the information regarding the number of teachers, the number of students, the number of classrooms and the number of graduates through interviews with and officially written petitions to the Ministry of National Education - Strategy Development Services.The number of students enrolled in a university was derived from the Periodicals Section under the title of Research, Publication and Statistics on the Measurement, Selection and Placement Center website, http://www.osym.gov.tr [40]. The success rate of YGS + LYS was obtained from the ratio of the number of students attending a university to the number of students who had taken the university exam.

\subsection{Efficiency Analysis with DEA}

The input-oriented DEA aims to investigate how the best input composition can be designed. The particular aim of this study was to determine how much input should be decreased/increased to improve the efficiency of inefficient schools, thus it was considered most convenient to use an inputoriented DEA model under the assumptions regarding constant returns to scale. EMS 1.3.0 (Efficiency Measurement System) software was used for the efficiency analysis. The results of the efficiency analysis with $47 \mathrm{DMU}$, and 3 input and 3 output variables are shown in Table 5. The schools in this table are given as DMU1, DMU2, DMU3, ........, DMU47. 
Table 5. Efficiency scores and reference groups of high schools (with DEA model)

\begin{tabular}{|c|c|c|}
\hline Anatolian High Schools & Efficiency scores & Referance Groups \\
\hline DMU1 & $58,53 \%$ & $3(0,11) \quad 17(0,83) \quad 40(0,00)$ \\
\hline DMU2 & $80,04 \%$ & $3(0,27) \quad 17(0,74)$ \\
\hline DMU3 & $100,00 \%$ & 8 \\
\hline DMU4 & $100,00 \%$ & 6 \\
\hline DMU5 & $60,76 \%$ & $4(0,10) 21(0,56) \quad 40(0,24)$ \\
\hline DMU6 & $66,72 \%$ & $17(0,51) 21(0,19) \quad 40(0,20)$ \\
\hline DMU7 & $58,56 \%$ & $17(0,17) 21(0,52) 40(0,22)$ \\
\hline DMU8 & $90,05 \%$ & $21(0,58) 40(0,38) 47(0,07)$ \\
\hline DMU9 & $87,47 \%$ & $3(0,05) 17(0,70) 40(0,02)$ \\
\hline DMU10 & $91,54 \%$ & $40(1,09)$ \\
\hline DMU11 & $83,24 \%$ & $4(0,10) 21(0,96)$ \\
\hline DMU12 & $87,21 \%$ & $21(0,78) 40(0,29)$ \\
\hline DMU13 & $54,86 \%$ & $17(0,62) 21(0,18) 40(0,09)$ \\
\hline DMU14 & $64,97 \%$ & $17(0,80) \quad 40(0,15)$ \\
\hline DMU15 & $51,57 \%$ & $4(0,06) 21(0,42) \quad 40(0,38)$ \\
\hline DMU16 & $67,98 \%$ & $17(0,20) \quad 40(0,46)$ \\
\hline DMU17 & $100,00 \%$ & 27 \\
\hline DMU18 & $65,05 \%$ & $21(0,67) 40(0,30)$ \\
\hline DMU19 & $58,07 \%$ & $17(0,48) \quad 40(0,28)$ \\
\hline DMU20 & $64,82 \%$ & $17(0,28) 21(0,49) 40(0,16)$ \\
\hline DMU21 & $100,00 \%$ & 22 \\
\hline DMU22 & $74,86 \%$ & $4(0,02) 21(0,91) \quad 40(0,06)$ \\
\hline DMU23 & $77,15 \%$ & $21(0,68) 40(0,33)$ \\
\hline DMU24 & $72,85 \%$ & $3(0,13) \quad 17(0,60) \quad 40(0,05)$ \\
\hline DMU25 & $70,21 \%$ & $17(0,64) 40(0,00)$ \\
\hline DMU26 & $71,29 \%$ & $3(0,20) \quad 17(0,54) \quad 40(0,05)$ \\
\hline DMU27 & $95,73 \%$ & $17(0,08) \quad 40(0,70)$ \\
\hline DMU28 & $70,93 \%$ & $4(0,04) 21(0,50) 40(0,34) 47(0,00)$ \\
\hline DMU29 & $66,95 \%$ & $17(0,62) 21(0,32) \quad 40(0,04)$ \\
\hline DMU30 & $81,64 \%$ & $3(0,00) \quad 17(0,84) 40(0,05)$ \\
\hline DMU31 & $59,46 \%$ & $17(1,08) 40(0,01)$ \\
\hline DMU32 & $90,49 \%$ & $3(0,09) \quad 40(1,04)$ \\
\hline DMU33 & $47,02 \%$ & $17(0,69) 40(0,10)$ \\
\hline DMU34 & $73,63 \%$ & $17(0,11) 21(0,90)$ \\
\hline DMU35 & $53,88 \%$ & $17(0,47) 21(0,49) 40(0,03)$ \\
\hline DMU36 & $64,70 \%$ & $21(0,79) 40(0,13)$ \\
\hline DMU37 & $58,22 \%$ & $4(0,05) 21(0,84) 40(0,09)$ \\
\hline DMU38 & $61,86 \%$ & $17(0,33) 21(0,29) \quad 40(0,23)$ \\
\hline DMU39 & $81,85 \%$ & $21(0,41) 40(0,31) 47(0,30)$ \\
\hline DMU40 & $100,00 \%$ & 38 \\
\hline DMU41 & $63,91 \%$ & $17(0,27) 21(0,49) 40(0,15)$ \\
\hline DMU42 & $55,83 \%$ & $3(0,02) \quad 17(0,38) 40(0,22)$ \\
\hline DMU43 & $36,20 \%$ & $17(0,37) \quad 40(0,28)$ \\
\hline DMU44 & $54,65 \%$ & $17(0,50) 21(0,27) 40(0,14)$ \\
\hline DMU45 & $81,42 \%$ & $17(0,81) \quad 40(0,04)$ \\
\hline DMU46 & $76,52 \%$ & $17(0,85) \quad 40(0,02)$ \\
\hline DMU47 & $100,00 \%$ & 3 \\
\hline
\end{tabular}

The analysis of Table 5 indicates that the efficiency scores column gives the percentage of efficiency in Anatolian High Schools. Schools with $100 \%$ efficiency are identified as efficient schools and the rest as inefficient. Accordingly, 6 schools were found efficient, which are DMU3 (Salih Dede Anatolian High School), DMU4 (Bornova Anatolian High School), DMU17 (Buca Fatma Saygin Anatolian High School), DMU21 (Buyukcigli Anatolian High School), DMU40 (Karatas Anatolian High School) and DMU47 (Ataturk High School), and 41 schools were inefficient within the scope of this study among which DMU27 (Gaziemir anatolian high school) had the highest efficiency scores and DMU43 (Namık Kemal High School) had the lowest. 
An analysis of the reference groups column suggested that DMU3 was taken as a reference point by inefficient schools for 8 times, DMU4 for 6 times, DMU17 for 27 times, DMU21 for 22 times, DMU40 for 38 times, and DMU 47 for 3 times, which shows that DMU40 was the most referred school in the list. The reference group column for inefficient schools also emphasized that to increase its efficiency, DMU27 referred to DMU17 with 8\% and DMU40 with 70\%. An example to show how to measure target values by using percentages in the reference group column is given below.

DMU27 $:$ : the target value of DMU27 for $i$. input.

$$
D M U 27_{i}=(0,08) D M U 17_{i}+(0,70) D M U 4 O_{i}
$$

DMU17 $:$ : the current value of DMU17 for $i$. input.

DMU40 ${ }_{\mathrm{i}}$ : the current value of DMU40 for $i$. input.

0,08: the weight of DMU17

0,70 : the weight of DMU40

Given the formula above, "the number of students" which is the 2 . input is measured as follows:

$$
D M U 27_{2}=(0,08)(350)+(0,70)(712)=526,4
$$

The current number of students of DMU27 was 630 and the target value for the number of students was noted to be 526. Consequently, it was suggested that the number of students should be reduced to 526 to increase the efficiency in this unit. Similarly, the number of teachers and classrooms of DMU27 were analyzed and it was stated that the unit had an efficiency level of $100 \%$ after establishing the target value and analyzing values by using a special program. The same procedure may as well be followed to find target values and improvement rates for other inefficient DMUs.

\subsection{Efficiency Analysis with DEAHP Model}

DEA is particularly available for evaluating the efficiency of DMUs with quantitative inputs and outputs. Each input and output are assumed to have equal significance. However, input and output values may not always bear significance at the same level. While some inputs or outputs may seem more elemental for the analysis, some may not. As a result, specifying the weights of input and output variables proves to be crucial in terms of providing healthy results. In this study, the input and output weights were identified by using an AHP model. These priority values were included in the analysis and the efficiency was measured again.

To identify the input and output weights, the researchers interviewed with 8 school counsellors from different high schools in İzmir and consequently binary comparison matrices were generated for inputs and outputs. It was reported that comparisons of four binaries were consistent and the weights of these matrices and input and output variables were identified. In the tables below (Table 6-13) the binary comparison matrices and consistency ratios are given.

Table 6. The binary comparison matrice of 1 st school counsellor for inputs

\begin{tabular}{|l|c|c|c|}
\hline Criteria & $\begin{array}{l}\text { The number } \\
\text { of teachers }\end{array}$ & $\begin{array}{l}\text { The number } \\
\text { of students }\end{array}$ & $\begin{array}{l}\text { The number } \\
\text { of classrooms }\end{array}$ \\
\hline $\begin{array}{l}\text { The number of } \\
\text { teachers }\end{array}$ & 1 & 4 & 3 \\
\hline $\begin{array}{l}\text { The number of } \\
\text { students }\end{array}$ & $1 / 4$ & 1 & $1 / 2$ \\
\hline $\begin{array}{l}\text { The number of } \\
\text { classrooms }\end{array}$ & $1 / 3$ & 2 & 1 \\
\hline CR=0,016 & & \\
\hline
\end{tabular}

Table 7. The binary comparison matrice of 1 st school counsellor for outputs

\begin{tabular}{|l|c|c|c|}
\hline Criteria & $\begin{array}{l}\text { The number of } \\
\text { graduate } \\
\text { students }\end{array}$ & $\begin{array}{l}\text { The number of } \\
\text { students } \\
\text { pursuing a } \\
\text { university } \\
\text { degree }\end{array}$ & $\begin{array}{l}\text { YGS+LYS } \\
\text { success rate }\end{array}$ \\
\hline $\begin{array}{l}\text { The number } \\
\text { of graduate } \\
\text { students }\end{array}$ & 1 & $1 / 8$ & $1 / 9$ \\
\hline $\begin{array}{l}\text { The number } \\
\text { of students } \\
\text { pursuing a } \\
\text { university } \\
\text { degree }\end{array}$ & 8 & 1 & $1 / 3$ \\
\hline $\begin{array}{l}\text { YGS+LYS } \\
\text { success rate }\end{array}$ & 9 & 3 & 1 \\
\hline CR=0,094 & & \\
\hline
\end{tabular}


Table 8. The binary comparison matrice of 2 nd school counsellor for inputs

\begin{tabular}{|l|l|l|l|}
\hline Criteria & $\begin{array}{l}\text { The } \\
\text { number of } \\
\text { teachers }\end{array}$ & $\begin{array}{l}\text { The } \\
\text { number of } \\
\text { students }\end{array}$ & $\begin{array}{l}\text { The } \\
\text { number of } \\
\text { classrooms }\end{array}$ \\
\hline $\begin{array}{l}\text { The number } \\
\text { of teachers }\end{array}$ & 1 & 3 & 2 \\
\hline $\begin{array}{l}\text { The number } \\
\text { of students }\end{array}$ & $1 / 3$ & 1 & $1 / 3$ \\
\hline $\begin{array}{l}\text { The number } \\
\text { of classrooms }\end{array}$ & $1 / 2$ & 3 & 1 \\
\hline CR=0,046 & & \\
\hline
\end{tabular}

Table 10. The binary comparison matrice of $3 \mathrm{rd}$ school counsellor for inputs

\begin{tabular}{|l|l|l|l|}
\hline Criteria & $\begin{array}{l}\text { The } \\
\text { number of } \\
\text { teachers }\end{array}$ & $\begin{array}{l}\text { The } \\
\text { number of } \\
\text { students }\end{array}$ & $\begin{array}{l}\text { The } \\
\text { number of } \\
\text { classrooms }\end{array}$ \\
\hline $\begin{array}{l}\text { The number } \\
\text { of teachers }\end{array}$ & 1 & 5 & 7 \\
\hline $\begin{array}{l}\text { The number } \\
\text { of students }\end{array}$ & $1 / 5$ & 1 & 3 \\
\hline $\begin{array}{l}\text { The number } \\
\text { of classrooms }\end{array}$ & $1 / 7$ & $1 / 3$ & 1 \\
\hline CR=0,057 &
\end{tabular}

Table 12. The binary comparison matrice of 4 th school counsellor for inputs

\begin{tabular}{|l|c|c|c|}
\hline Criteria & $\begin{array}{l}\text { The } \\
\text { number of } \\
\text { teachers }\end{array}$ & $\begin{array}{l}\text { The number } \\
\text { of students }\end{array}$ & $\begin{array}{l}\text { The } \\
\text { number of } \\
\text { classrooms }\end{array}$ \\
\hline $\begin{array}{l}\text { The number } \\
\text { of teachers }\end{array}$ & 1 & 5 & 4 \\
\hline $\begin{array}{l}\text { The number } \\
\text { of students }\end{array}$ & $1 / 5$ & 1 & $1 / 3$ \\
\hline $\begin{array}{l}\text { The number } \\
\text { of classrooms }\end{array}$ & $1 / 4$ & 3 & 1 \\
\hline CR=0,075 & \multicolumn{2}{|l}{} \\
\hline
\end{tabular}

Table 9. The binary comparison matrice of 2 nd school counsellor for outputs

\begin{tabular}{|l|c|c|c|}
\hline Criteria & $\begin{array}{l}\text { The number } \\
\text { of graduate } \\
\text { students }\end{array}$ & $\begin{array}{l}\text { The number } \\
\text { of students } \\
\text { pursuing a } \\
\text { university } \\
\text { degree }\end{array}$ & $\begin{array}{l}\text { YGS+LYS } \\
\text { success rate }\end{array}$ \\
\hline $\begin{array}{l}\text { The number } \\
\text { of graduate } \\
\text { students }\end{array}$ & 1 & $1 / 7$ & $1 / 8$ \\
\hline $\begin{array}{l}\text { The number } \\
\text { of students } \\
\text { pursuing a } \\
\text { university } \\
\text { degree }\end{array}$ & 7 & 1 & $1 / 3$ \\
\hline $\begin{array}{l}\text { YGS+LYS } \\
\text { success rate }\end{array}$ & 8 & 3 & 1 \\
\hline CR=0,091 & & \\
\hline
\end{tabular}

Table 11. The binary comparison matrice of $3 \mathrm{rd}$ school counsellor for outputs

\begin{tabular}{|l|c|l|c|}
\hline Criteria & $\begin{array}{l}\text { The number } \\
\text { of graduate } \\
\text { students }\end{array}$ & $\begin{array}{l}\text { The number } \\
\text { of students } \\
\text { pursuing a } \\
\text { university } \\
\text { degree }\end{array}$ & $\begin{array}{l}\text { YGS+LYS } \\
\text { success } \\
\text { rate }\end{array}$ \\
\hline $\begin{array}{l}\text { The number of } \\
\text { graduate } \\
\text { students }\end{array}$ & 1 & $1 / 6$ & $1 / 9$ \\
\hline $\begin{array}{l}\text { The number of } \\
\text { students } \\
\text { pursuing a } \\
\text { university } \\
\text { degree }\end{array}$ & 6 & 1 & $1 / 4$ \\
\hline $\begin{array}{l}\text { YGS+LYS } \\
\text { success rate }\end{array}$ & 9 & 4 & 1 \\
\hline CR=0,095 & & & \\
\hline
\end{tabular}

Table 13. The binary comparison matrice of 4th school counsellor for outputs

\begin{tabular}{|l|c|c|c|}
\hline Criteria & $\begin{array}{l}\text { The number } \\
\text { of graduate } \\
\text { students }\end{array}$ & $\begin{array}{l}\text { The number } \\
\text { of students } \\
\text { pursuing a } \\
\text { university } \\
\text { degree }\end{array}$ & $\begin{array}{l}\text { YGS+LYS } \\
\text { success } \\
\text { rate }\end{array}$ \\
\hline $\begin{array}{l}\text { The number of } \\
\text { graduate } \\
\text { students }\end{array}$ & 1 & $1 / 7$ & $1 / 9$ \\
\hline $\begin{array}{l}\text { The number of } \\
\text { students } \\
\text { pursuing a } \\
\text { university degree }\end{array}$ & 7 & 1 & $1 / 3$ \\
\hline $\begin{array}{l}\text { YGS+LYS } \\
\text { success rate }\end{array}$ & 9 & 3 & 1 \\
\hline CR=0,070 & & \\
\hline
\end{tabular}


As consistency rates are $\mathrm{CR}<0,1$, it can be therefore deduced that binary comparison matrices are consistent in tables above. The percentages of significance for input and output variables calculated by using matrices are given in Table 14 and Table 15, respectively.

Table 14. Percentages of significance for input variables

\begin{tabular}{|l|c|c|c|c|c|}
\hline Inputs & $\begin{array}{c}\text { 1st school } \\
\text { counsellor (1st } \\
\text { decision } \\
\text { maker) }\end{array}$ & $\begin{array}{c}\text { 2nd school } \\
\text { counsellor (2nd } \\
\text { decision } \\
\text { maker) }\end{array}$ & $\begin{array}{c}\text { 3rd school } \\
\text { counsellor (3rd } \\
\text { decision maker) }\end{array}$ & $\begin{array}{c}\text { 4th school } \\
\text { counsellor } \\
\text { (4th decision } \\
\text { maker) }\end{array}$ & $\begin{array}{c}\text { Average } \\
\text { Weigth }\end{array}$ \\
\hline $\begin{array}{l}\text { The number of } \\
\text { teachers }\end{array}$ & 0,623 & 0,525 & 0,724 & 0,665 & 0,634 \\
\hline $\begin{array}{l}\text { The number of } \\
\text { students }\end{array}$ & 0,137 & 0,141 & 0,193 & 0,104 & 0,144 \\
\hline $\begin{array}{l}\text { The number of } \\
\text { classrooms }\end{array}$ & 0,240 & 0,334 & 0,083 & 0,231 & 0,222 \\
\hline Total & 1,000 & 1,000 & 1,000 & 1,000 & 1,000 \\
\hline
\end{tabular}

Table 15. Percentages of significance for output variables

\begin{tabular}{|l|c|c|c|c|c|}
\hline Outputs & $\begin{array}{l}\text { 1st school } \\
\text { counsellor } \\
\text { (1st decision } \\
\text { maker) }\end{array}$ & $\begin{array}{l}\text { 2nd school } \\
\text { counsellor } \\
\text { (2nd decision } \\
\text { maker) }\end{array}$ & $\begin{array}{l}\text { 3rd school } \\
\text { counsellor } \\
\text { (3rd decision } \\
\text { maker) }\end{array}$ & $\begin{array}{l}\text { 4th school } \\
\text { counsellor } \\
\text { (4th decision } \\
\text { maker) }\end{array}$ & $\begin{array}{l}\text { Average } \\
\text { Weigth }\end{array}$ \\
\hline $\begin{array}{l}\text { The number of } \\
\text { graduate students }\end{array}$ & 0,054 & 0,061 & 0,059 & 0,057 & 0,058 \\
\hline $\begin{array}{l}\text { The number of } \\
\text { students pursuing a } \\
\text { university degree }\end{array}$ & 0,306 & 0,302 & 0,251 & 0,295 & 0,288 \\
\hline $\begin{array}{l}\text { YGS+LYS success } \\
\text { rate }\end{array}$ & 0,640 & 0,637 & 0,690 & 0,648 & 0,654 \\
\hline Total & 1,000 & 1,000 & 1,000 & 1,000 & 1,000 \\
\hline
\end{tabular}

The analysis of the charts indicates that the number of teachers input variable had the highest significance value with $63,4 \%$ and that YGS + LYS success rate output variable had the highest significance value with $65,4 \%$.

The top three input variables were the number of teachers, the number of classrooms and the number of students while the top three output variables were YGS+LYS success rate, the number of students pursuing a university degree and the number of graduate students, respectively.

\begin{tabular}{c|ccc} 
Inputs & $i_{1}$ & $i_{2}$ & $i_{3}$ \\
\hline$i_{1}$ & 1 & 4,16 & 3,6 \\
$i_{2}$ & 0,24 & 1 & 0,64 \\
$i_{3}$ & 0,28 & 1,56 & 1
\end{tabular}

\begin{tabular}{c|ccc} 
Outputs & $o_{1}$ & $o_{2}$ & $o_{3}$ \\
\hline$o_{1}$ & 1 & 0,144 & 0,114 \\
$o_{2}$ & 6,96 & 1 & 0,31 \\
$o_{3}$ & 8,74 & 3,22 & 1
\end{tabular}

The input (i) and output (o) variable matrices were analyzed and 6 limitations were added to DEA models.

$$
\begin{aligned}
& \frac{\mathrm{i}_{1}}{\mathrm{i}_{2}} \geq 4,16 \quad i_{1}-4,16 \mathrm{i}_{2} \geq 0 \quad ; \quad \frac{\mathrm{i}_{1}}{\mathrm{i}_{3}} \geq 3,6 \quad \mathrm{i}_{1}-3,6 \mathrm{i}_{3} \geq 0 \\
& \frac{\mathrm{i}_{2}}{\mathrm{i}_{3}} \geq 0,64 \quad \mathrm{i}_{2}-0,64 \mathrm{i}_{3} \geq 0 \quad ; \quad \frac{\mathrm{o}_{1}}{\mathrm{o}_{2}} \geq 0,144 \quad o_{1}-0,144 o_{2} \geq 0 \\
& \frac{\mathrm{o}_{1}}{\mathrm{o}_{3}} \geq 0,114 \quad \mathrm{o}_{1}-0,114 \mathrm{o}_{3} \geq 0 \quad ; \quad \frac{\mathrm{o}_{2}}{\mathrm{o}_{3}} \geq 0,31 \quad \mathrm{o}_{2}-0,31 \mathrm{o}_{3} \geq 0
\end{aligned}
$$


With the addition of these 6 limitations to the model, the weights were included in the analysis and the efficiency measurement for 47 high schools was repeated with EMS 1.3.0 program. The efficiency scores of the weights included in the analysis and the reference groups of the DMUs are given in Table 16.

Table 16. Efficiency scores and reference groups (with DEAHP model)

\begin{tabular}{|c|c|c|}
\hline Anatolian High Schools & Efficiency scores & Reference groups \\
\hline DMU1 & $41,12 \%$ & $3(0,11) 4(0,14)$ \\
\hline DMU2 & $53,73 \%$ & $3(0,42) 4(0,08)$ \\
\hline DMU3 & $100,00 \%$ & 28 \\
\hline DMU4 & $100,00 \%$ & 37 \\
\hline DMU5 & $55,28 \%$ & $4(0,25) \quad 40(0,24)$ \\
\hline DMU6 & $53,31 \%$ & $4(0,16) \quad 40(0,16)$ \\
\hline DMU7 & $51,16 \%$ & $3(0,06) 4(0,18) 40(0,17)$ \\
\hline DMU8 & $78,22 \%$ & $3(0,05) 4(0,35) 40(0,08)$ \\
\hline DMU9 & $50,61 \%$ & $3(0,03) 4(0,05) 40(0,10)$ \\
\hline DMU10 & $91,54 \%$ & $40(1,09)$ \\
\hline DMU11 & $73,74 \%$ & $3(0,12) \quad 4(0,33)$ \\
\hline DMU12 & $69,88 \%$ & $3(0,12) 4(0,31)$ \\
\hline DMU13 & $40,43 \%$ & $4(0,18) \quad 40(0,04)$ \\
\hline DMU14 & $37,28 \%$ & $40(0,30)$ \\
\hline DMU15 & $47,98 \%$ & $4(0,17) \quad 40(0,38)$ \\
\hline DMU16 & $60,81 \%$ & $40(0,49)$ \\
\hline DMU17 & $66,55 \%$ & $3(0,04) 4(0,15)$ \\
\hline DMU18 & $51,81 \%$ & $3(0,03) 4(0,25) 40(0,13)$ \\
\hline DMU19 & $44,34 \%$ & $3(0,00) 4(0,06) \quad 40(0,30)$ \\
\hline DMU20 & $53,93 \%$ & $3(0,03) 4(0,19) 40(0,12)$ \\
\hline DMU21 & $87,35 \%$ & $3(0,14) 4(0,23)$ \\
\hline DMU22 & $62,22 \%$ & $4(0,27) \quad 40(0,05)$ \\
\hline DMU23 & $63,91 \%$ & $4(0,28) \quad 40(0,13)$ \\
\hline DMU24 & $49,82 \%$ & $3(0,10) 4(0,06) 40(0,10)$ \\
\hline DMU25 & $27,63 \%$ & $3(0,05) 4(0,00) \quad 40(0,11)$ \\
\hline DMU26 & $48,80 \%$ & $3(0,13) 4(0,03) 40(0,16)$ \\
\hline DMU27 & $86,49 \%$ & $40(0,72)$ \\
\hline DMU28 & $66,88 \%$ & $3(0,09) \quad 4(0,19) \quad 40(0,28)$ \\
\hline DMU29 & $48,35 \%$ & $4(0,21)$ \\
\hline DMU30 & $51,87 \%$ & $3(0,03) \quad 4(0,12) \quad 40(0,05)$ \\
\hline DMU31 & $38,64 \%$ & $3(0,02) 4(0,17)$ \\
\hline DMU32 & $88,70 \%$ & $3(0,23) 40(0,96)$ \\
\hline DMU33 & $27,96 \%$ & $3(0,04) 4(0,07) \quad 40(0,12)$ \\
\hline DMU34 & $58,03 \%$ & $4(0,26)$ \\
\hline DMU35 & $41,10 \%$ & $3(0,03) \quad 4(0,22)$ \\
\hline DMU36 & $54,65 \%$ & $3(0,26) 4(0,20)$ \\
\hline DMU37 & $49,55 \%$ & $4(0,28) 40(0,07)$ \\
\hline DMU38 & $51,54 \%$ & $4(0,15) \quad 40(0,20)$ \\
\hline DMU39 & $73,89 \%$ & $3(0,11) 4(0,48) 40(0,08)$ \\
\hline DMU40 & $100,00 \%$ & 32 \\
\hline DMU41 & $52,00 \%$ & $4(0,19) \quad 40(0,12)$ \\
\hline DMU42 & $40,16 \%$ & $3(0,00) 40(0,29)$ \\
\hline DMU43 & $27,59 \%$ & $40(0,34)$ \\
\hline DMU44 & $42,65 \%$ & $3(0,00) 4(0,18) \quad 40(0,10)$ \\
\hline DMU45 & $45,92 \%$ & $3(0,02) 4(0,09) 40(0,07)$ \\
\hline DMU46 & $41,81 \%$ & $3(0,06) 4(0,09) 40(0,03)$ \\
\hline DMU47 & $89,25 \%$ & $3(0,06) 4(0,94)$ \\
\hline
\end{tabular}

It was suggested that there was a slight decline in the number of efficient schools in Table 16 after adding the weight limitations to DEA model by using AHP. It was further noted that in this table, there 
were only 3 schools with $100 \%$ efficiency score. The target values for input variables of inefficient DMUs on the basis of reference groups in Table 16 are given in Table 17.

Table 17. Target values for inefficient DMUs after DEAHP

\begin{tabular}{|c|c|c|c|}
\hline & \multicolumn{3}{|c|}{ target values } \\
\hline Anatolian High & the number of & the number of & the number of \\
\hline DMU1 & 18,42 & 230,04 & 9,88 \\
\hline DMU2 & 26,24 & 227,88 & 11,36 \\
\hline DMU3 & \multicolumn{3}{|c|}{$100 \%$ efficient. } \\
\hline DMU4 & \multicolumn{3}{|c|}{$100 \%$ efficient. } \\
\hline DMU5 & 36,97 & 528,63 & 20,02 \\
\hline DMU6 & 24 & 342,88 & 12,96 \\
\hline DMU7 & 29,11 & 394,82 & 15,31 \\
\hline DMU8 & 40,39 & 571,31 & 22,94 \\
\hline DMU9 & 11,47 & 150,85 & 5,68 \\
\hline DMU10 & 57,77 & 776,08 & 25,07 \\
\hline DMU11 & 37,29 & 504,63 & 21,06 \\
\hline DMU12 & 35,35 & 476,01 & 19,9 \\
\hline DMU13 & 19,58 & 286,06 & 11,36 \\
\hline DMU14 & 15,9 & 213,6 & 6,9 \\
\hline DMU15 & 36,63 & 513,83 & 18,6 \\
\hline DMU16 & 25,97 & 348,88 & 11,27 \\
\hline DMU17 & 16,31 & 225,45 & 9,34 \\
\hline DMU18 & 32,46 & 458,41 & 17,97 \\
\hline DMU19 & 21,72 & 299,46 & 10,38 \\
\hline DMU20 & 26,11 & 365,43 & 14,26 \\
\hline DMU21 & 28,47 & 366,93 & 15,58 \\
\hline DMU22 & 28,84 & 421,97 & 16,81 \\
\hline DMU23 & 34,05 & 493,24 & 19,23 \\
\hline DMU24 & 15,52 & 184,06 & 7,38 \\
\hline DMU25 & 8,03 & 91,82 & 3,33 \\
\hline DMU26 & 17,11 & 191,95 & 7,5 \\
\hline DMU27 & 38,16 & 512,64 & 16,56 \\
\hline DMU28 & 37,23 & 495,55 & 18,9 \\
\hline DMU29 & 20,37 & 300,51 & 12,18 \\
\hline DMU30 & 15,61 & 215,42 & 8,59 \\
\hline DMU31 & 17,37 & 248,67 & 10,18 \\
\hline DMU32 & 61 & 745,62 & 25,76 \\
\hline DMU33 & 14,91 & 196,41 & 7,46 \\
\hline DMU34 & 25,22 & 372,06 & 15,08 \\
\hline DMU35 & 22,66 & 322,92 & 13,24 \\
\hline DMU36 & 30,84 & 356,4 & 15,76 \\
\hline DMU37 & 30,87 & 450,52 & 17,85 \\
\hline DMU38 & 25,15 & 357,05 & 13,3 \\
\hline DMU39 & 55,64 & 773,54 & 31,44 \\
\hline DMU40 & \multicolumn{3}{|c|}{$100 \%$ efficient. } \\
\hline DMU41 & 24,79 & 357,33 & 13,78 \\
\hline DMU42 & 15,37 & 206,48 & 6,67 \\
\hline DMU43 & 18,02 & 242,08 & 7,82 \\
\hline DMU44 & 22,76 & 328,78 & 12,74 \\
\hline DMU45 & 13,32 & 184,03 & 7,15 \\
\hline DMU46 & 12,96 & 166,35 & 6,87 \\
\hline DMU47 & 93,82 & 1361,34 & 55,48 \\
\hline
\end{tabular}

Inefficient institutions will reach $100 \%$ efficiency when they adjust their input values in accordance with Table 17.

Tablo 18. Efficient Schools according to DEA and DEAHP analyses

\begin{tabular}{|l|l|}
\hline Efficient Schools according to DEA & Efficient Schools according to DEAHP analyses \\
\hline Salih Dede anatolian high school (DMU3) & Salih Dede anatolian high school (DMU3) \\
\hline Bornova anatolian high school (DMU4) & Bornova anatolian high school (DMU4) \\
\hline Buca Fatma Saygın anatolian high school (DMU17) & Karataş anatolian high school (DMU40) \\
\hline Büyükçiğli anatolian high school (DMU21) & \\
\hline Karataş anatolian high school (DMU40) & \\
\hline Atatürk High School (DMU 47) & \\
\hline
\end{tabular}


As seen in Table 18, the number of efficient schools was 6 in DEA while it decreased to 3 after including expert opinions in the analysis, and efficiency scores of Buca Fatma Saygin Anatolian High School, Büyükçiğli Anatolian High School and Atatürk High School were reported to be less than $100 \%$.

Tablo 19. A comparison of efficiency scores with DEA and DEAHP models.

\begin{tabular}{|c|c|c|}
\hline Anatolian High Schools & Efficiency scores with DEA & Efficiency scores with DEAHP integrated model \\
\hline DMU1 & $58,53 \%$ & $41,12 \%$ \\
\hline DMU2 & $80,04 \%$ & $53,73 \%$ \\
\hline DMU3 & $100,00 \%$ & $100,00 \%$ \\
\hline DMU4 & $100,00 \%$ & $100,00 \%$ \\
\hline DMU5 & $60,76 \%$ & $55,28 \%$ \\
\hline DMU6 & $66,72 \%$ & $53,31 \%$ \\
\hline DMU7 & $58,56 \%$ & $51,16 \%$ \\
\hline DMU8 & $90,05 \%$ & $78,22 \%$ \\
\hline DMU9 & $87,47 \%$ & $50,61 \%$ \\
\hline DMU10 & $91,54 \%$ & $91,54 \%$ \\
\hline DMU11 & $83,24 \%$ & $73,74 \%$ \\
\hline DMU12 & $87,21 \%$ & $69,88 \%$ \\
\hline DMU13 & $54,86 \%$ & $40,43 \%$ \\
\hline DMU14 & $64,97 \%$ & $37,28 \%$ \\
\hline DMU15 & $51,57 \%$ & $47,98 \%$ \\
\hline DMU16 & $67,98 \%$ & $60,81 \%$ \\
\hline DMU17 & $100,00 \%$ & $66,55 \%$ \\
\hline DMU18 & $65,05 \%$ & $51,81 \%$ \\
\hline DMU19 & $58,07 \%$ & $44,34 \%$ \\
\hline DMU20 & $64,82 \%$ & $53,93 \%$ \\
\hline DMU21 & $100,00 \%$ & $87,35 \%$ \\
\hline DMU22 & $74,86 \%$ & $62,22 \%$ \\
\hline DMU23 & $77,15 \%$ & $63,91 \%$ \\
\hline DMU24 & $72,85 \%$ & $49,82 \%$ \\
\hline DMU25 & $70,21 \%$ & $27,63 \%$ \\
\hline DMU26 & $71,29 \%$ & $48,80 \%$ \\
\hline DMU27 & $95,73 \%$ & $86,49 \%$ \\
\hline DMU28 & $70,93 \%$ & $66,88 \%$ \\
\hline DMU29 & $66,95 \%$ & $48,35 \%$ \\
\hline DMU30 & $81,64 \%$ & $51,87 \%$ \\
\hline DMU31 & $59,46 \%$ & $38,64 \%$ \\
\hline DMU32 & $90,49 \%$ & $88,70 \%$ \\
\hline DMU33 & $47,02 \%$ & $27,96 \%$ \\
\hline DMU34 & $73,63 \%$ & $58,03 \%$ \\
\hline DMU35 & $53,88 \%$ & $41,10 \%$ \\
\hline DMU36 & $64,70 \%$ & $54,65 \%$ \\
\hline DMU37 & $58,22 \%$ & $49,55 \%$ \\
\hline DMU38 & $61,86 \%$ & $51,54 \%$ \\
\hline DMU39 & $81,85 \%$ & $73,89 \%$ \\
\hline DMU40 & $100,00 \%$ & $100,00 \%$ \\
\hline DMU41 & $63,91 \%$ & $52,00 \%$ \\
\hline DMU42 & $55,83 \%$ & $40,16 \%$ \\
\hline DMU43 & $36,20 \%$ & $27,59 \%$ \\
\hline DMU44 & $54,65 \%$ & $42,65 \%$ \\
\hline DMU45 & $81,42 \%$ & $45,92 \%$ \\
\hline DMU46 & $76,52 \%$ & $41,81 \%$ \\
\hline DMU47 & $100,00 \%$ & $89,25 \%$ \\
\hline
\end{tabular}

The efficiency scores were comparatively analyzed with DEA model and DEAHP models and the results were given in Table 19. 3 of the 6 schools that were previously found effective with DEA model were not considered to be $100 \%$ effective with DEAHP model. However, efficiency scores 
decreased with the addition of weights. It was concluded that healthier and more reliable results were achieved only when these variables were included in the analysis with AHP model rather than giving equal weight values to the input and output variables.

\section{CONCLUSION AND RECOMMENDATIONS}

Considering that the education system plays a vital role in the development and welfare of countries, conducting studies on the efficiency of educational institutions and improving their organizational structure are urgently required, which, indeed, accounts for a growing number of studies on education system every year. This particular study was conducted to evaluate the efficiency of Anatolian high schools in İzmir and to provide guidance to the ineffective institutions to become effective, and most importantly, to contribute to the education system. This study stands out as the first in its kind to use DEAHP integrated model in assessing the efficiency of Anatolian high schools in İzmir.

In the study, 47 Anatolian High Schools were selected as DMUs in the central districts of İzmir. Afterwards, 3 input and 3 output variables were selected that best represent the high school education processes. The study data were collected in the 2015-2016 academic year and were analyzed with EMS 1.3.0 package program. After identifying and establishing variables and collecting data, the efficiency was measured with DEA model. Finally, weights were assigned to the input and output variables with AHP model, efficiency analysis was repeated with DEAHP integrated model.

The initial measurement with DEA suggested that 6 schools were $100 \%$ efficient and the efficiency scores of the 41 schools remained below 100\%. It was reported that Namik Kemal High School had the lowest efficiency score with $36,20 \%$. As a result of the analysis, the target value was calculated for DMU27, Gaziemir Anatolian High School. The current number of students attending Gaziemir Anatolian High School was 630. The results suggested that the target value for the number of students was 526 and the number of students should be reduced to increase efficiency. As for the number of teachers and classrooms, the target value was calculated and analyzed with the help of the program and the unit reached $100 \%$ efficiency.

In the analysis conducted with DEAHP model, binary comparison matrices were used to assign weights to input and output variables with reference to the expert opinions of four counsellors whose opinions were considered to be consistent and then the efficiency analysis was conducted. It was concluded that the efficiency scores of 3 schools decreased which were previously noted to be efficient according to DEA model, and that only 3 schools were found efficient according to DEAHP model. The average significance values were calculated on the basis of binary comparison matrices of the inputs and outputs generated with the expert opinions of counsellors and it was reported that the three input variables with highest significance values were the number of teachers, number of classrooms and the number of students, respectively. Likewise, three output variables with highest significance values were YGS + LYS success rate, the number of students pursuing a university degree, and the number of graduates, respectively.

As a result, it is recommended that efficient Anatolian high schools maintain their efficiency levels and that inefficient institutions specify their optimum input levels, that is, their target values, by modeling efficient institutions on improving their efficiency as identified with DEAHP model. It is also strongly suggested that these efficiency analyses be repeated at regular intervals to (re)establish target values and conduct further researches to promote the improvement of our education system.

\section{ACKNOWLEDGEMENTS}

This research was conducted as a part of master's thesis of Reyhan Ayna, which was supported by The Scientific Research Council of Ege University under 15FEN031. 
Ayna and Elmastaş Gültekin / Eskişehir Technical Univ. J. of Sci. and Tech. A-Appl. Sci. and Eng. 20 (1) - 2019

\section{REFERENCES}

[1] Stern ZS, Mehrez A and Hadad Y. An AHP/DEA modelology for ranking decision making units, International Transactions In Operational Research, 2000; 7, 109-124 pp.

[2] Lee SK, Mogi G, Shin SC and Kim JW. An AHP/DEA integrated model for measuring the relative efficiency of energy efficiency technologies, 2007; IEEE, 55-59 pp.

[3] Korpela J, Lehmusvaara A and Nisonen J. Warehouse operator selection by combining AHP and DEA modelologies, International Journal of Production Economics, 2007; 108, 135-142 pp.

[4] Sevkli M., Koh, SCL, Zaim S, Demirbag M and Tatoglu E. An application of data envelopment analytic hierarchy process for supplier selection: a case study of BEKO in Turkey, International Journal of Production Research, 2007; 45(9), 1973-2003 pp.

[5] Wang YM, Liu J and Elhag TMS. An integrated AHP-DEA modelology for bridge risk assessment, Computers\&Industrial Engineering, 2008; 54, 513-525 pp.

[6] Erpolat $\mathrm{S}$ ve Cinemre N. Notebook seçiminde hibrit bir yaklaşım: analitik hiyerarşi yöntemine dayalı veri zarflama analizi, İstanbul Üniversitesi İşletme Fakültesi Dergisi, 2011; 40(2), 207-225 s.

[7] Lin MI, Lee YD and Ho TN, Applying integrated DEA/AHP to evaluate the economic performance of local governments in China, European Journal of Operational Research, 2011; 209, 129-140 pp.

[8] Doğan NÖ ve Gencan S. VZA/AHP bütünleşik yöntemi ile performans ölçümü: Ankara'daki kamu hastaneleri üzerine bir uygulama, Gazi Üniversitesi İktisadi ve İdari Bilimler Fakültesi Dergisi, 2014; 16(2), 88-112 s.

[9] Mahapatra B, Mukherjee K and Bhar C. Performance measurement-an AHP-DEA based approach, Journal of Advanced Management Science, 2015; 3(1), 26-30 pp.

[10] Öztürk O ve Girginer N. Türk tekstil ve hazır giyim firmalarının ihracat etkinliği: veri zarflama analizi (VZA) ve Analitik Hiyerarşi Süreci (AHS) kullanımıyla bir inceleme, Tekstil ve Konfeksiyon, 2015; 25(1), 10-23 s.

[11] Mimovic P and Krstic A. The integrated application of the AHP and the DEA models in evaluating the performances of higher education institutions in the respublic of Serbia, Economic Horizons, 2016; 18(1), 73-86 pp.

[12] Çağlar A ve Öztaş GZ, Veri zarflama analizi ve analitik hiyerarşi süreci ile sigorta şirketlerinin finansal oran analizi, Çankırı Karatekin Üniversitesi İktisadi ve İdari Bilimler Fakültesi Dergisi, 2016; 6(2), 221-248 s.

[13] Pakkar MS. Hierarchy grey relational analysis using DEA and AHP, PSU Research Review, 2017; 1(2), 150-163 pp.

[14] Thanassoulis E, Dey PK, Petridis K, Goniadis I. and Georgiou AC. Evaluating higher education teaching performance using combined analytic hierarchy process and data envelopment analysis, Journal of the Operational Research Society, 2017; 68, 431-445 pp. 
Ayna and Elmastaş Gültekin / Eskişehir Technical Univ. J. of Sci. and Tech. A-Appl. Sci. and Eng. 20 (1) - 2019

[15] Baş İM ve Artar A. İşletmelerde Verimlilik Denetimi: Ölçme ve Değerlendirme Modelleri, Milli Prodüktivite Merkezi Yayınları, 1991; 435, Ankara, 423s.

[16] Sink DS and Tuttle TC. Planning and Measurement in your Organization of the Future, Industrial Engineering and Management Press, 1989; Norcross, GA.

[17] Yeşilyurt C ve Alan MA. Fen liselerinin 2002 y1lı göreceli etkinliğinin veri zarflama analizi (VZA) yöntemi ile ölçülmesi, C.Ü. İktisadi ve İdari Bilimler Dergisi, 2003; 4(2), 91-104 s.

[18] Sarı Z. Veri Zarflama Analizi ve Bir Uygulama, Yüksek Lisans Tezi, Hacettepe Üniversitesi Fen Bilimleri Enstitüsü, İstatistik Anabilim Dal1, 2015; Ankara, 72s.

[19] Sarıca S. Üniversitelerin Performansa Göre Yönetimi için Veri Zarflama Analizi Tabanlı Bir Karar Destek Sisteminin Tasarımı ve Geliştirilmesi, Yüksek Lisans Tezi, Eskişehir Osmangazi Üniversitesi Fen Bilimleri Enstitüsü, Endüstri Mühendisliği Anabilim Dalı, Eskişehir, 2007; 91s.

[20] Karaca C. Veri Zarflama Analizi ile Antalya Bölgesindeki Ziraat Bankası Şubelerinin Performans Değerlendirmesi, Yüksek Lisans Tezi, Gazi Üniversitesi, Fen Bilimleri Enstitüsü, İstatistik Anabilim Dalı, Ankara, 2010; 105s.

[21] Deliktaş E. Türkiye özel sektör imalat sanayiinde etkinlik ve toplam faktör verimliliği analizi, ODTÜ Gelişim Dergisi, 2002; 29(3-4), 247-284 s.

[22] Charnes A, Cooper WW and Rhodes E. Measuring the efficiency of decision making units, North-Holland Publishing Company, European Journal of Operational Research, 1978; 2, 429$444 \mathrm{pp}$.

[23] Korhonen P. Searching the efficient frontier in data envelopment analysis, IIASA Interim Report, International Institute for Applied Systems Analysis, Laxenburg, Austria, 1997; 15p.

[24] Hadad Y, Friedman L and Hanani ZM. Measuring efficiency of restaurants using the data envelopment analysis modelology, Computer Modelling and New Technologies, 2007; 11(4), 25$35 \mathrm{pp}$.

[25] Haas DA, Evaluating the Efficiency of Municipal Reverse Logistics Channels: An Application of Data Envelopment Analysis, Doctoral Dissertation, Temple University, 1998; 276p.

[26] Depren Ö. Veri Zarflama Analizi ve Bir Uygulama, Yüksek Lisans Tezi, Yıldız Teknik Üniversitesi, Fen Bilimleri Enstitüsü, İstanbul, 2008; 117s.

[27] Yoluk M. Hastane Performansının Veri Zarflama Analizi (VZA) Yöntemi ile Değerlendirilmesi, Yüksek Lisans Tezi, Atılım Üniversitesi, Sosyal Bilimler Enstitüsü, Sağlık Kurumları İsletmeciliği Anabilim Dalı, Ankara, 2010; 121s.

[28] Farrell MJ. The measurement of productive efficiency, Journal of the Royal Statistical Society, 1957; 120(3), 253-290 pp.

[29] Sowlati T. Establishing the Practical Frontier in Data Envelopment Analysis, University of Toronto, Canada, 2001; 151p.

[30] Cooper W, Seiford L and Tune K. Data Envelopment Analysis- A Comprehensive Text with Models, Applications, References and DEA-Solver Software, Kluwer Academic Publishers, Hingham-US. 1999. 
Ayna and Elmastaş Gültekin / Eskişehir Technical Univ. J. of Sci. and Tech. A-Appl. Sci. and Eng. 20 (1) - 2019

[31] Eroğlu H. Bankacılıkta Veri Zarflama Analizi Uygulaması, Yüksek Lisans Tezi, İstanbul Teknik Üniversitesi, Fen Bilimleri Enstitüsü, İstanbul, 2007; 132 s.

[32] Banker RD, Charnes A and Cooper WW. Some models for estimating technical and scale inefficiencies in data envelopment analysis, Management Science, 1984; 30(9), 1078-1092 pp.

[33] Bowlin WF. Evaluating the efficiency of US air force real - property maintenance activities, The Journal of the Operational Research Society, 1987; 38(2), 127-135 pp.

[34] Kecek G. Veri Zarflama Analizi Teori ve Uygulama Örneği, Siyasal Kitabevi, Ankara 2010; 180 s.

[35] Budak H. Veri Zarflama Analizi ve Hisse Senedi Seçiminde Bir Uygulama, Yüksek Lisans Tezi, Gazi Üniversitesi Fen Bilimleri Enstitüsü, İstatistik Anabilim Dalı, Ankara 2010; 88s.

[36] Özden ÜH. Analitik hiyerarşi yöntemi ile ilkokul seçimi, Marmara Üniversitesi, İ.İ.B.F. Dergisi, 2008; 14(1), 299-320 s.

[37] Saaty TL. The Analytic Hierarchy Process, McGraw-Hill, 1980; New York.

[38] Ramanathan R. Data envelopment analysis for weight derivation and aggregation in the analytic hierarchy process, Computers\&Operations Research, 2006; 33, 1289-1307 pp.

[39] Subramanyam T. Selection of input-output variables in Data Envelopment Analysis-Indian Commercial Banks, International Journal of Computer \& Mathematical Sciences, 2016; 5(6), 5157.

[40] Ölçme, Seçme ve Yerleştirme Merkezi Başkanlığı, 'Ortaöğretim Kurumlarına göre 2016 Öğrenci Seçme ve Yerleştirme Sistemi Sonuçları Kitabı', http://www.osym.gov.tr/TR,12734/2016-yiliyayinlari.html (Erişim tarihi: 20.04.2017). 